\title{
ELASTIC CONSTANTS OF CHILEAN Pinus radiata USING ULTRASOUND
}

\author{
Erik Baradit ${ }^{1, \AA}$ \\ https://orcid.org/0000-0002-2014-3696 \\ Cecilia Fuentealba ${ }^{2}$ \\ https://orcid.org/0000-0002-1763-9463 \\ Miguel Yáñez ${ }^{3}$ \\ https://orcid.org/0000-0001-5483-3428
}

\begin{abstract}
In general, data regarding the mechanical properties of wood is still incomplete, mainly owing to the difficulties involved in preparing well-made standard testing samples, as well as the time-consuming evaluation tests. Therefore, the elastic constants for Pinus radiata in this paper were determined using ultrasound technology. In parallel, typical compression mechanical testing was carried out to compare the effectiveness of the nondestructive test using the ultrasound. The longitudinal elastic constant values were similar to the mechanical testing (ultrasound was $12,8 \%$ higher than mechanical testing), showing that ultrasound technique is a reliable and valid tool. The values for radial and tangential moduli obtained by the ultrasound versus mechanical testing showed statistically significant differences. This may be due to the difficulty in obtaining adequate samples for mechanical testing. The symmetry of the shear modulus was revealed by the ultrasound technique $\left(\mathrm{G}_{\mathrm{ij}}=\mathrm{G}_{\mathrm{ji}}\right.$ ). Poisson's ratios were not comparable using either method; however, values obtained were more consistent with the existing literature for Pinus species. Additionally, the elastic anisotropy of the analyzed wood samples was demonstrated through the ultrasound velocity propagation in the material. It was thus possible to obtain the twelve engineering constants that characterize the mechanical behavior of wood employing of the proposed ultrasound technique. The results proved that this technique could be a useful tool for such characterization.
\end{abstract}

Keywords: Elastic constant, nondestructive evaluation, Pinus radiata, Poisson's ratio, shear rate, ultrasound, wave propagation.

\section{INTRODUCTION}

Forestry is the second most important economic activity in Chile after copper mining. In 2018, roundwood consumption reached 43 million $\mathrm{m}^{3}$ (solid wood base) as a raw material in the forestry industry (Hernández and Elgueta 2020). The main commercial species are Pinus radiata and Eucalyptus sp. In sawmills, the use of radiata pine approaches $96 \%$.

In Chile, however, the use of wood amounts to only $18 \%$ of the materials used in the construction sector (Hernández and Elgueta 2020). This may be due to insecurity regarding wood as an engineering material: wood is a biological resource with poor fungal and fire resistance and may therefore have low outdoor exposure resistance due to its hygroscopic character. Another limiting factor is the lack of information about the variability of the mechanical properties of wood, according to species, age, moisture, treatments, among others 
(Bodig and Jayne 1993). All these aspects have a negative impact on the use of wood in the building sector. Structural design calculation software requires complete information about the mechanical properties of the wood used in order to achieve accurate prediction of its behavior, and said data is often not fully known or available (Kotlínová et al. 2010, Gonçalves et al. 2011, De Borst et al. 2013).

Wood is a heterogeneous and anisotropic material. Its mechanical properties are unique and independent along its three main axes: longitudinal (parallel to wood grain), radial (perpendicular to growing rings) and tangential (perpendicular to grain but tangential to rings). To characterize the elastic properties of wood, nine different elastic constants are required: three elastic moduli (Young's modulus) $\left(\mathrm{E}_{\mathrm{LL}}, \mathrm{E}_{\mathrm{RR}}, \mathrm{E}_{\mathrm{TT}}\right)$, three shear moduli $\left(\mathrm{G}_{\mathrm{LR}}=\mathrm{G}_{\mathrm{RL}}, \mathrm{G}_{\mathrm{LT}}=\mathrm{G}_{\mathrm{LT}}, \mathrm{G}_{\mathrm{RT}}=\mathrm{G}_{\mathrm{RT}}\right)$, and three Poisson's ratios $\left(v_{\mathrm{LR}}=v_{\mathrm{RL}}, v_{\mathrm{LT}}=v_{\mathrm{TL}}, v_{\mathrm{RT}}=v_{\mathrm{TR}}\right)$. These constants are experimentally determined through mechanical testing; however, due to the nature of the wood, said testing is not easily performed. Nondestructive techniques (NDT) have emerged such as ultrasound (Bucur 1983, Baradit and Niemz 2012, Gonçalves et al. 2014, Crespo et al. 2017, Espinosa et al. 2018), X-ray (Perré and Badel 2003), optical digital measurements (Majano-Majano et al. 2012), and more sophisticated techniques such as nanoindentation (Gindl et al. 2004, Konnerth et al. 2010).

The longitudinal elastic modulus $\left(\mathrm{E}_{\mathrm{LL}}\right)$ has been studied more than the other constants, given the difficulty in determining the latter. For example, it is well known that the elastic modulus varies with species, moisture content, temperature, among others. Nevertheless, some relationships have been experimentally determined, such as $\mathrm{E}_{\mathrm{LL}}: \mathrm{E}_{\mathrm{RR}}: \mathrm{E}_{\mathrm{TT}} \approx 20: 1,6: 1$ and $\mathrm{G}_{\mathrm{LR}}: \mathrm{G}_{\mathrm{LT}}: \mathrm{G}_{\mathrm{RT}} \approx 10: 9,4: 1$ (Bodig and Jayne 1993).

Ultrasonic wave propagation has been reported as a fast and effective method to determine the elastic constants of wood (Bucur 2006, Gonçalves et al. 2011). This is relevant considering the destructive nature of mechanical testing and the difficulty of determining the different properties of wood due to its high variability. Other aspects that bear mentioning are the cost of performing a high number of tests as well as the complexity of both the test and the manufacturing of the specimens. This method is particularly important for obtaining information on the shear modulus and Poisson's ratios (Keunecke et al. 2007). Different studies have been carried out on native woods and radiata pine using ultrasound, which has provided useful information regarding their elastic constants (Niemz and Aguilera 1995, Sonderegger et al. 2010, Baradit and Niemz 2012).

In this study, the elastic moduli, shear modulus, and Poisson's ratios of Pinus radiata were determined by ultrasound (US) and mechanical testing. Our goal was to use the fast and convenient ultrasound method to fully characterize this wood's mechanical properties, some of which were heretofore unknown or available only from theoretical analysis.

\section{Theory}

The use of US for determining elastic constants is based on the theory of solids and elastic wave propagation. The symmetry of wood is similar to an orthotropic crystal with orthogonal axes corresponding to the main directions of the tree (L-longitudinal, R-radial, and T-tangential). Twelve constants that completely characterize the elastic properties are related to Equation 1.

$$
\left[\begin{array}{c}
\gamma_{L} \\
\gamma_{R} \\
\gamma_{T} \\
\gamma_{R T} \\
\gamma_{L T} \\
\gamma_{L R}
\end{array}\right]=\left[\begin{array}{cccccc}
\frac{1}{E_{L}} & -\frac{v_{R L}}{E_{R}} & -\frac{v_{T L}}{E_{T}} & 0 & 0 & 0 \\
-\frac{v_{L R}}{E_{L}} & \frac{1}{E_{R}} & -\frac{v_{T R}}{E_{T}} & 0 & 0 & 0 \\
-\frac{v_{L T}}{E_{L}} & -\frac{v_{R T}}{E_{R}} & \frac{1}{E_{T}} & 0 & 0 & 0 \\
0 & 0 & 0 & \frac{1}{G_{R T}} & 0 & 0 \\
0 & 0 & 0 & 0 & 1 / G_{L T} & 0 \\
0 & 0 & 0 & 0 & 0 & 1 / G_{L R}
\end{array}\right]\left[\begin{array}{c}
\sigma_{L} \\
\sigma_{R} \\
\sigma_{T} \\
\sigma_{R T} \\
\sigma_{L T} \\
\sigma_{L R}
\end{array}\right]
$$


In Equation 1 the diagonal terms of the compliance matrix are related to elastic and shear moduli for the three main directions; the non-diagonal terms are related to Poisson's ratios. All of these constants can be obtained through transverse and longitudinal polarization waves in the material, using different angles (Royer and Dieulesaint 2000). This is described by Christoffels Equation 2.

$$
\left|\Gamma_{i l}-\rho \delta_{i l} V^{2}\right|=0
$$

Where $\Gamma_{i j}=C_{i j k l} n_{i} n_{j}$ a second tensor, $C_{i j k l}$-elastic constants $\left(\mathrm{N} / \mathrm{m}^{2}\right), \mathrm{n}_{\mathrm{i}}$-direction cosines, $\rho$-density $(\mathrm{kg} /$ $\left.\mathrm{m}^{3}\right), \delta_{i j}$-Kronecker tensor, V-velocity of wave propagation $(\mathrm{m} / \mathrm{s})$. In Equation 2 for each main direction of the tree, there are two velocities of wave propagation with different polarizations.

\section{MATERIALS AND METHODS}

\section{Raw material}

The samples were obtained from five 20-year-old trees of Pinus radiata D. Don, in the Arauco region in Chile. Samples of $130 \mathrm{~mm} \times 130 \mathrm{~mm} \times 1500 \mathrm{~mm}$ were taken from the $5^{\text {th }}$ ring of each tree, creating five groups. The samples were conditioned to assure a $12 \%$ moisture content (MC) in a climate-controlled room set at 23 ${ }^{\circ} \mathrm{C} \pm 1 \%$ and $50 \% \pm 3 \%$ humidity (INN 1984). Once the desired MC was attained, the wood samples were prepared in order to obtain samples for both US and mechanical testing. Density was calculated according to standard procedure (INN 1988).

\section{Ultrasonic testing}

To obtain the non-diagonal terms of Equation 1, cubes of $20 \mathrm{~mm} \pm 1 \mathrm{~mm}$ were oriented at different angles following the main direction of the tree. Seventy of these cubes were obtained from each group (10 for each angle: $0^{\circ}, 15^{\circ}, 30^{\circ}, 45^{\circ}, 105^{\circ}, 120^{\circ}$ and $135^{\circ}$ ), for a total of 350 samples.

The cubes for the three planes, LR, LT, and RT, are shown in Figure 1. Elastic moduli and shear moduli were determined with the $0^{\circ}$ orientation. Density was registered for each cube in Table 1 .
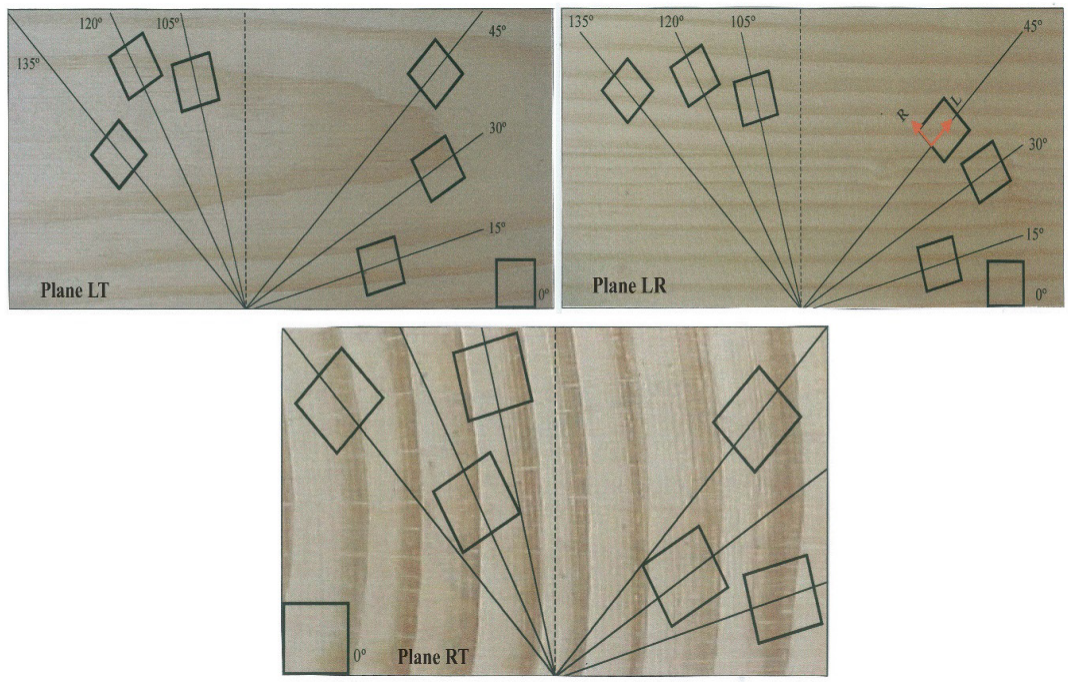

Figure 1: Samples for ultrasonic testing plane LT: longitudinal-tangential, plane LR: longitudinal-radial, plane RT: radial-tangential 
Table 1: Average density at $12 \% \mathrm{MC}$ of samples oriented to $0^{\circ}$ and oriented off the main axis.

\begin{tabular}{|c|c|c|c|c|}
\hline \multirow{2}{*}{ Tree } & Density at $0^{\circ}$ & \multicolumn{3}{|c|}{ Density (samples off main axis) $\left(\mathrm{kg} / \mathrm{m}^{3}\right)$} \\
\cline { 3 - 5 } & $\left(\mathrm{kg} / \mathrm{m}^{3}\right)$ & LR & LT & TR \\
\hline 1 & $482,0(2,8)$ & $424,1(187,1)$ & $480,7(111,8)$ & $452,9(129,2)$ \\
\hline 2 & $454,5(13,2)$ & $470,0(109,4)$ & $418,4(117,2)$ & $451,0(131,1)$ \\
\hline 3 & $414,6(56,9)$ & $382,9(110,7)$ & $457,5(135,8)$ & $417,3(126,0)$ \\
\hline 4 & $558,2(21,4)$ & $458,0(110,8)$ & $523,0(127,5)$ & $459,4(130,4)$ \\
\hline 5 & $430,0(43,3)$ & $400,5(151,9)$ & $400,3(155,0)$ & $448,0(130,9)$ \\
\hline
\end{tabular}

Plane LT: longitudinal-tangential, plane LR: longitudinal-radial, plane RT: radial-tangential Standard deviations shown in parentheses

The average density of the samples shows a wide range $\left(415 \mathrm{~kg} / \mathrm{m}^{3}\right.$ to $\left.558 \mathrm{~kg} / \mathrm{m}^{3}\right)$, mainly due to varying proportions of earlywood or latewood and juvenile and mature wood in the samples, as was expected. This parameter strongly influences ultrasound velocity (Equation 2).

The US measurement was carried out using Panametrics 5800PR transmission equipment and transducers of $1 \mathrm{MHz}$ with longitudinal and transverse polarization, V103 and V153. A pulse is generated and sent to an emission transducer sending the signal through the samples, which is then received by a receptor-transducer. The travel time between the two transducers (delay time) was measured by means of an oscilloscope, and used to calculate the propagation velocity (Figure 2).

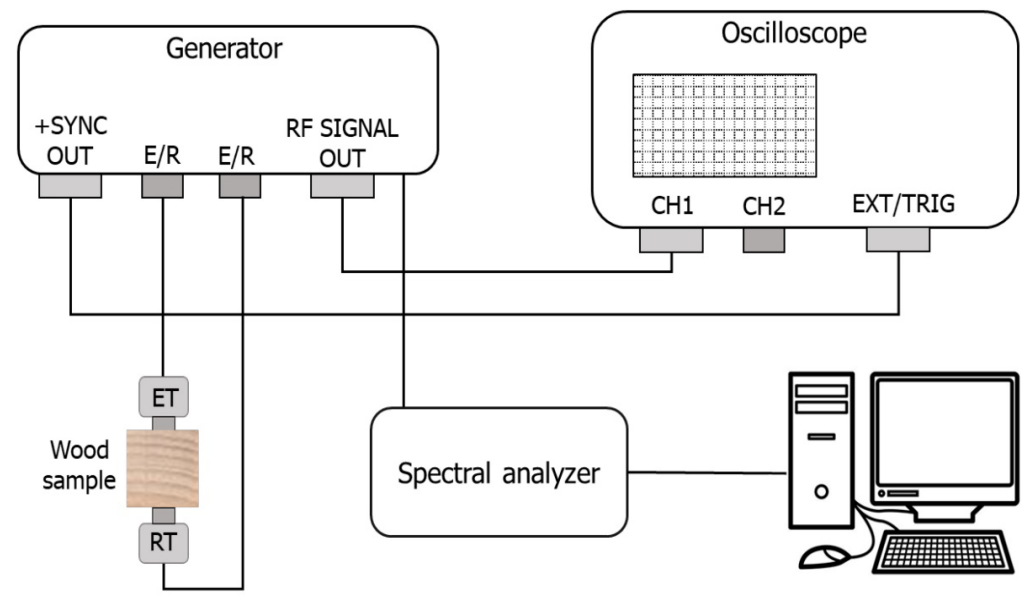

ET: Emissor transducer; RT: Receptor transducer

Figure 2: Ultrasonic system configuration.

A total of 50 samples were used to obtain the average for each velocity $\mathrm{V}_{\mathrm{ij}}$. For cubes oriented to $0^{\circ}$, nine characteristic times were obtained corresponding to nine propagation velocities, while for cubes oriented off the main axis, two propagation velocities were obtained: quasi-longitudinal velocity using a longitudinal polarization transducer and a quasi-transversal velocity using a transverse polarization transducer.

\section{Mechanical testing}

Three sample groups were made per tree for the compression mechanical testing, corresponding to the longitudinal, radial, and tangential directions. Each group was composed of five samples making a total of 75 . The size of the samples was $50 \mathrm{~mm} \times 50 \mathrm{~mm} \times 200 \mathrm{~mm}( \pm 1 \mathrm{~mm})$ for parallel-to-grain (longitudinal) and 50 $\mathrm{mm} \times 50 \mathrm{~mm} \times 100 \mathrm{~mm}( \pm 1 \mathrm{~mm})$ for perpendicular-to-grain (tangential and radial) directions in accordance with NCh 973/1986 (INN 1986a) and NCh 974/1986 (INN 1986b), respectively.

The load cycle was performed in a Universal Instron machine and the deformations at different loads were acquired with a data logger. To obtain both the elasticity moduli and Poisson ratio, the deformations were mea- 
sured by strain gauge KL-10-120-A4 (Kyowa) placed in the wood sample according to the required strains, as shown in Figure 3. When the load was parallel-to-grain, i.e longitudinal direction, three strain gauges were placed in the sample. To obtain the elasticity moduli $\mathrm{E}_{\mathrm{LL}}$, one of the said gauges was placed along the longitudinal direction, and for the Poisson's ratio calculations $v_{L R}$ and $v_{L T}$, the other two were placed along the radial and tangential directions, respectively. When the load was along the radial direction, only two strain gauges were placed in the sample. In this case, to obtain the elasticity moduli $\mathrm{E}_{\mathrm{RR}}$ one strain gauge was placed along the radial direction, and for Poisson's ratio $v_{\mathrm{RT}}$ the other was placed along the tangential direction. When the load was along the tangential direction, only one strain gauge was placed in the sample in this direction to determine the elasticity moduli $\mathrm{E}_{\mathrm{TT}}$. Poisson's ratios $v_{\mathrm{TR}}$ and $v_{\mathrm{TL}}$ were determined using symmetry properties.

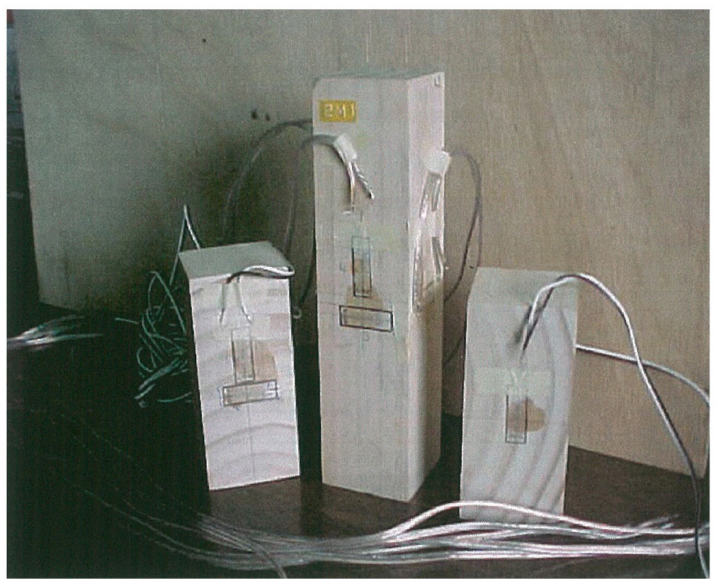

Figure 3: Wood samples with strain gauges for mechanical testing.

\section{Elastic constant calculations}

The six diagonal terms in the Equation 1 were obtained from Christoffel's Equation 2. The elastic constants are expressed by Equation 3:

$$
C_{i j k l}=C_{\alpha \beta}=\rho V^{2}
$$

According to the orthotropic symmetry of wood, four indexes are changed for two in the elastic constants (Royer and Dieulesaint 2000): $\alpha$ - direction of polarization, and $\beta$-direction of propagation, $(\alpha, \beta=1,2,3,4,5,6)$. Particularly, the shear moduli were calculated by Equation 4:

$$
G_{i j}=G_{j i}=\frac{1}{2} \rho\left(V_{i j}^{2}+V_{j i}^{2}\right)
$$

For off-diagonal terms in the matrix, an iterative process was developed relating compliance off-terms to the matrix $\left(\mathrm{S}_{\mathrm{ij}}\right)$ with the elastic constants $C_{i j}$ and $C_{i i}$ (Bodig and Jayne 1993).

The iterative process begins by setting the six diagonal coefficients $\mathrm{C}_{\mathrm{ii}}$ and all combinations between the non-diagonal coefficients $\mathrm{C}_{\mathrm{ij}}$ Both $\mathrm{C}_{\mathrm{ii}}$ and $\mathrm{C}_{\mathrm{ij}}$ were experimentally obtained by US. After this, the next determinant was calculated by Equation 5 :

$$
\Delta C=C_{11} C_{22} C_{33}+2 C_{12} C_{13} C_{23}-C_{12}^{2} C_{33}-C_{23}^{2} C_{11}-C_{13}^{2} C_{22}
$$

To obtain different coefficients $\mathrm{S}_{\mathrm{ij}}$ of the Compliance matrix, only combinations with positive determinants $\Delta \mathrm{C}$ were considered. From this process, a group of solutions for technical constants was obtained. To optimize the results, the elastic constant must satisfy the physical and mechanical properties of 
the wood. The $\mathrm{E}_{\mathrm{LL}}, \mathrm{E}_{\mathrm{RR}}$, and $\mathrm{E}_{\mathrm{TT}}$ values must be positive and fall within the following ranges: $7500(\mathrm{MPa})$ $<\mathrm{E}_{\mathrm{LL}}<15000(\mathrm{MPa}) ; 500(\mathrm{MPa})<\mathrm{E}_{\mathrm{TT}}<1500(\mathrm{MPa}) ; \mathrm{E}_{\mathrm{RR}}>1000(\mathrm{MPa}) ;$ and Poisson's ratios $v_{\mathrm{ij}}<1$.

\section{RESULTS AND DISCUSSION}

\section{Density}

The density values at $12 \%$ moisture content are shown in Table 2 .

Table 2: Average density at $12 \%$ moisture content in samples oriented along the three main directions for mechanical testing.

\begin{tabular}{|c|c|c|c|}
\hline \multirow{2}{*}{ Tree } & \multicolumn{4}{|c|}{ Average density $\left(\mathrm{kg} / \mathrm{m}^{3}\right)$ by orientation } \\
\cline { 2 - 4 } & Parallel & Tangential & Radial \\
\hline 1 & $458,1(15,0)$ & $456,4(21,3)$ & $446,8(34,8)$ \\
\hline 2 & $443,8(24,8)$ & $426,8(13,6)$ & $420,2(20,2)$ \\
\hline 3 & $422,0(20,0)$ & $413,0(12,0)$ & $416,0(9,9)$ \\
\hline 4 & $412,0(40,0)$ & $454,0(87,7)$ & $450,0(33,1)$ \\
\hline 5 & $388,0(20,0)$ & $462,0(20,0)$ & $436,0(18,4)$ \\
\hline
\end{tabular}

Standard deviations shown in parentheses

Due to the intrinsic nature of wood, the samples exhibit a wide range of densities. The samples used for mechanical testing show less variability in comparison to those used for ultrasound testing. This is most likely due to smaller specimens containing a higher proportion of latewood or earlywood, which is closely related to greater variability in density (note, for example, the large tangential orientation deviation observed for tree 4).

\section{Shear modulus}

The shear modulus obtained by the ultrasound technique using a shear polarization transducer is shown in Table 3. As expected, similar symmetry in propagation velocity was observed. Because of this symmetry, the average values for this modulus were 1230,4 MPa for the LR plane; 887,6 MPa for the LT plane, and 113,2 MPa for the RT plane. The relationship between them (LR:LT:RT) was 11:7,9:1; which is consistent with the literature for wood (Bodig and Jayne 1993).

Table 3: Symmetry of the shear modulus determined by ultrasonic testing.

\begin{tabular}{|c|c|c|c|c|c|c|c|c|c|}
\hline \multirow{2}{*}{ Tree ID } & \multicolumn{5}{|c|}{ Propagation velocity } & \multicolumn{3}{c|}{$\begin{array}{c}\text { Shear modulus } \\
(\mathrm{m} / \mathrm{s})\end{array}$} \\
\cline { 2 - 11 } & $\mathrm{V}_{\mathrm{LR}}$ & $\mathrm{V}_{\mathrm{RL}}$ & $\mathrm{V}_{\mathrm{RT}}$ & $\mathrm{V}_{\mathrm{TR}}$ & $\mathrm{V}_{\mathrm{LT}}$ & $\mathrm{V}_{\mathrm{TL}}$ & $\mathrm{G}_{\mathrm{LR}}$ & $\mathrm{G}_{\mathrm{LT}}$ & $\mathrm{G}_{\mathrm{RT}}$ \\
\hline 1 & 1569 & 1673 & 519 & 541 & 1422 & 1371 & 1265 & 946 & 135 \\
\hline 2 & 1585 & 1619 & 504 & 464 & 1456 & 1392 & 1166 & 921 & 108 \\
\hline 3 & 1605 & 1611 & 456 & 400 & 1325 & 1370 & 1066 & 747 & 79 \\
\hline 4 & 1582 & 1607 & 532 & 524 & 1299 & 1338 & 1409 & 963 & 154 \\
\hline 5 & 1640 & 1657 & 432 & 467 & 1377 & 1363 & 1246 & 861 & 90 \\
\hline Average & 1596,2 & 1633,4 & 488,6 & 479,2 & 1375,8 & 1368,8 & 1230,4 & 887,6 & 113,2 \\
\hline $\mathrm{SD}^{\mathrm{a}}$ & 27,7 & 29,7 & 42,8 & 55,9 & 65,3 & 20,4 & 127,0 & 87,6 & 31,1 \\
\hline $\mathrm{CV}^{\mathrm{b}}(\%)$ & 1,7 & 1,8 & 8,8 & 11,7 & 4,7 & 1,5 & 10,3 & 9,9 & 27,5 \\
\hline
\end{tabular}

${ }^{\mathrm{a} S t a n d a r d}$ deviation; ${ }^{\mathrm{b}}$ Coefficient of variation.

\section{Modulus of elasticity and wood anisotropy}

Table 4 shows the elastic moduli obtained by means of mechanical compression tests and ultrasonic measurements for the different directions using longitudinal polarization transducers. As expected, the elastic moduli in the longitudinal direction of the tree for both the mechanical and ultrasonic tests are higher than in the other directions, and in both types of tests, it is observed that $\mathrm{E}_{\mathrm{LL}}>\mathrm{E}_{\mathrm{RR}}>\mathrm{E}_{\mathrm{TT}}$.

The values are consistent with the literature (Bodig and Jayne 1993), except for the elasticity modu- 
lus in the radial direction $\left(\mathrm{E}_{\mathrm{RR}}\right)$ obtained in the mechanical test, whose value was significantly higher than that obtained by ultrasound $(\mathrm{t}=6,019 ; \mathrm{p}$-valor $=0,000003<0,01)$. For example, during the compression mechanical test in the radial direction, characteristics such as the height and the ring curvature of the wood sample affected the elasticity modulus calculation (Liu and Ross 2005). In the radial direction, earlywood and latewood bands were arranged in series, perpendicular to the applied load. Both bands carried the same load, but latewood deformed much less than earlywood (Kennedy 1968). This phenomenon did not occur when ultrasound propagation waves travelled through the wood sample, and the $\mathrm{E}_{\mathrm{RR}}$ obtained by ultrasound was closely correlated with the radial modulus described by Liu and Ross (2005).

Table 4: Modulus of elasticity obtained by mechanical and ultrasonic testing.

\begin{tabular}{|c|c|c|c|c|c|c|}
\hline \multirow{2}{*}{ Tree ID } & \multicolumn{3}{|c|}{ Mechanical testing } & \multicolumn{3}{c|}{ Ultrasonic testing } \\
\cline { 2 - 7 } & \multicolumn{2}{|c|}{ Modulus of elasticity (MPa) } & \multicolumn{3}{c|}{ Modulus of elasticity (MPa) } \\
\cline { 2 - 7 } & $\begin{array}{c}\text { Longitudinal } \\
\mathrm{E}_{\mathrm{LL}}\end{array}$ & $\begin{array}{c}\text { Radial } \\
\mathrm{E}_{\mathrm{RR}}\end{array}$ & $\begin{array}{c}\text { Tangential } \\
\mathrm{E}_{\mathrm{TT}}\end{array}$ & $\begin{array}{c}\text { Longitudinal } \\
\mathrm{E}_{\mathrm{LL}}\end{array}$ & $\begin{array}{c}\text { Radial } \\
\mathrm{E}_{\mathrm{RR}}\end{array}$ & $\begin{array}{c}\text { Tangential } \\
\mathrm{E}_{\mathrm{TT}}\end{array}$ \\
\hline 1 & 9204 & 1080 & 714 & 13362 & 2250 & 840 \\
\hline 2 & 10257 & - & 678 & 11370 & 2062 & 777 \\
\hline 3 & 10581 & 946 & 693 & 9768 & 1786 & 682 \\
\hline 4 & 8896 & 1071 & 575 & 11924 & 2245 & 917 \\
\hline 5 & 9145 & 1132 & 539 & 8741 & 1891 & 656 \\
\hline Average & 9616,6 & 1057,2 & 639,8 & 11033,0 & 2046,8 & 774,4 \\
\hline SD & 750,4 & 78,9 & 77,7 & 1815,6 & 208,0 & 108,6 \\
\hline CV $(\%)$ & 7,0 & 6,5 & 10,9 & 14,7 & 9,1 & 12,5 \\
\hline
\end{tabular}

Table 5 shows the relationship between the elasticity moduli $\mathrm{E}_{\mathrm{LL}}, \mathrm{E}_{\mathrm{RR}}$, and $\mathrm{E}_{\mathrm{TT}}$ described by other research (Bodig and Jayne 1993, Forest Products Laboratory 2010) and compared to the ultrasound tests. Averages and standard deviations were obtained using the Bootstrap re-sampling estimation method (Efron 1979, Efron and Tibshirani 1993).

Mechanical tests show a 15:1,7:1 ratio for $\mathrm{E}_{\mathrm{LL}} / \mathrm{E}_{\mathrm{TT}}: \mathrm{E}_{\mathrm{RR}} / \mathrm{E}_{\mathrm{TT}}: \mathrm{E}_{\mathrm{TT}} / \mathrm{E}_{\mathrm{TT}}$, whereas for ultrasound said ratio is 14:2,6:1. Therefore, a similar relationship exists between moduli in longitudinal and tangential directions. However, this is not the case for moduli in the radial direction: said value is higher compared with the mechanical test, mainly due to the absence of ring curvature and the highest density. Additionally, the elastic moduli relationships obtained by other authors in pine species are shown in Table 5 (Bodig and Jayne 1993, Forest Products Laboratory 2010).

Table 5: Relationship among moduli of elasticity.

\begin{tabular}{|c|c|c|c|c|c|c|}
\hline \multirow{3}{*}{ Tree ID } & \multicolumn{3}{|c|}{ Mechanical testing } & \multicolumn{3}{|c|}{ Ultrasonic testing } \\
\hline & \multicolumn{3}{|c|}{ Modulus of elasticity (MPa) } & \multicolumn{3}{|c|}{ Modulus of elasticity (MPa) } \\
\hline & $\begin{array}{c}\text { Longitudinal } \\
\mathrm{E}_{\mathrm{LL}}\end{array}$ & $\begin{array}{c}\text { Radial } \\
E_{R R}\end{array}$ & $\begin{array}{c}\text { Tangential } \\
\mathrm{E}_{\mathrm{TT}}\end{array}$ & $\begin{array}{c}\text { Longitudinal } \\
\mathrm{E}_{\mathrm{LL}}\end{array}$ & $\begin{array}{c}\text { Radial } \\
E_{R R}\end{array}$ & $\begin{array}{c}\text { Tangential } \\
\mathrm{E}_{\mathrm{TT}}\end{array}$ \\
\hline Average $^{c}$ & 9829 & 1085 & 651 & 10,834 & 2,017 & 768 \\
\hline SD & 516,0 & 43,0 & 26,0 & 461,0 & 51,5 & 26,3 \\
\hline \multirow[t]{2}{*}{ CV $(\%)$} & 5,3 & 3,9 & 4,0 & 4,3 & 2,6 & 3,4 \\
\hline & \multicolumn{3}{|c|}{$\mathrm{E}_{\mathrm{LI}} / \mathrm{E}_{\mathrm{TT}}: \mathrm{E}_{\mathrm{RR}} / \mathrm{E}_{\mathrm{TT}}: \mathrm{E}_{\mathrm{TT}} / \mathrm{E}_{\mathrm{TT}}$} & \multicolumn{3}{|c|}{$\mathrm{E}_{\mathrm{LL}} / \mathrm{E}_{\mathrm{TT}}: \mathrm{E}_{\mathrm{RR}} / \mathrm{E}_{\mathrm{TT}}: \mathrm{E}_{\mathrm{TT}} / \mathrm{E}_{\mathrm{TT}}$} \\
\hline Results & \multicolumn{3}{|c|}{$15: 1,7: 1$} & \multirow{3}{*}{\multicolumn{3}{|c|}{$14: 2,6: 1$}} \\
\hline $\begin{array}{c}\text { Bodig and Jane } \\
\text { (1993) }\end{array}$ & \multicolumn{3}{|c|}{$20: 1,6: 1$} & & & \\
\hline FPL (2010) & \multicolumn{3}{|c|}{$12: 1,5: 1$} & & & \\
\hline
\end{tabular}

${ }^{\mathrm{c} B o o t s t r a p}$ estimation average.

Table 6 summarizes the results for sample anisotropy, measured as the ratio between different propagation 
velocities of longitudinal polarization. The differences observed reflect the anatomical structure of wood favoring the mechanical transmission of energy in the longitudinal direction with respect to radial and tangential directions. This is due to the wood's cell arrangements. The values obtained are consistent for the different wood species studied, and they coincide with results by Kollmann (1968) and Bucur (2006) for softwoods. In addition, a greater standard deviation was observed for the modulus of elasticity. This may be because the longitudinal velocity is strongly affected by the grain inclination, and as radiata pine is a rapid growth species, it is not easy to find perfectly aligned fibers.

Table 6: Anisotropy of wood measured by the wave propagation velocity.

\begin{tabular}{|c|c|c|c|c|c|c|c|c|c|c|c|c|}
\hline \multirow{3}{*}{ Tree ID } & \multicolumn{6}{|c|}{ Mechanical testing } & \multicolumn{6}{|c|}{ Ultrasonic testing } \\
\hline & \multicolumn{6}{|c|}{ Poisson's ratio } & \multicolumn{6}{|c|}{ Poisson's ratio ${ }^{d}$} \\
\hline & $v_{\mathrm{LR}}$ & $v_{\mathrm{LT}}$ & $v_{\mathrm{RT}}$ & $v_{\mathrm{TR}}$ & $v_{\mathrm{RL}}$ & $v_{\mathrm{TL}}$ & $v_{\mathrm{LR}}$ & $v_{\mathrm{LT}}$ & $v_{\mathrm{RT}}$ & $v_{\mathrm{TR}}$ & $v_{R L}$ & $v_{\mathrm{TL}}$ \\
\hline 1 & 0,544 & 0,401 & 0,792 & 0,524 & 0,064 & 0,031 & \multirow{5}{*}{0,300} & \multirow{5}{*}{0,210} & \multirow{5}{*}{0,634} & \multirow{5}{*}{0,253} & \multirow{5}{*}{0,047} & \multirow{5}{*}{0,013} \\
\hline 2 & 0,544 & 0,510 & - & - & - & 0,034 & & & & & & \\
\hline 3 & 0,522 & 0,421 & 0,826 & 0,605 & 0,047 & 0,028 & & & & & & \\
\hline 4 & 0,487 & 0,441 & - & - & 0,059 & 0,029 & & & & & & \\
\hline 5 & 0,549 & 0,459 & 0,532 & 0,253 & 0,068 & 0,027 & & & & & & \\
\hline Average & 0,529 & 0,446 & 0,430 & 0,276 & 0,048 & 0,030 & 0,300 & 0,210 & 0,634 & 0,253 & 0,047 & 0,013 \\
\hline SD & 0,026 & 0,042 & 0,161 & 0,184 & 0,009 & 0,003 & & & & & & \\
\hline CV (\%) & 4,9 & 9,4 & 37,4 & 66,7 & 18,8 & 10,0 & & & & & & \\
\hline
\end{tabular}

\section{Poisson's ratio}

The Poisson's ratios were calculated by means of an iterative process where both coefficients $C_{i i}$ and $\mathrm{C}_{\mathrm{ij}}$, calculated experimentally, were used to satisfy the Equation 1 conditions. Poisson's ratio values from mechanical and ultrasound testing are shown in Table 7.

Mechanical tests present a high variability attributed to the difficulty in carrying out the test, particularly the geometry and ring curvature in the wood samples. Nevertheless, the values obtained in both tests are higher than those typically reported in the literature, especially for Pinus species, e.g, 0,3 - 0,44 (Bodig and Jayne 1993, Forest Products Laboratory 2010). For the ultrasound test, the Poisson's ratios are lower and are more in line with the literature; $v_{\mathrm{LR}}, v_{\mathrm{LT}}$, and $v_{\mathrm{RT}}$ of 0,$3 ; 0,2$, and 0,634 , respectively. Furthermore, the dynamic test using ultrasound showed differences with respect to the static test (mechanical) for $v_{\mathrm{LR}}$, consistent with the results of Gonçalves et al. (2011).

Table 7: Poisson's ratio values obtained by mechanical and ultrasound methods.

\begin{tabular}{|c|c|c|c|c|}
\hline \multirow{2}{*}{ Tree ID } & \multicolumn{4}{|c|}{ Propagation velocity $(\mathrm{m} / \mathrm{s})$} \\
\cline { 2 - 4 } & $\mathrm{V}_{\mathrm{LL}}$ & $\mathrm{V}_{\mathrm{RR}}$ & $\mathrm{V}_{\mathrm{TT}}$ & $\mathrm{V}_{\mathrm{LL}} \mathrm{V}_{\mathrm{RR}:} \mathrm{V}_{\mathrm{TT}}$ \\
\hline 1 & 5267 & 2161 & 1320 & $1: 2,4: 4,0$ \\
\hline 2 & 4986 & 2130 & 1308 & $1: 2,3: 3,8$ \\
\hline 3 & 4821 & 2082 & 1289 & $1: 2,3: 3,7$ \\
\hline 4 & 4647 & 2014 & 1288 & $1: 2,3: 3,6$ \\
\hline 5 & 4481 & 2097 & 1233 & $1: 2,1: 3,6$ \\
\hline Average & 4840 & 2097 & 1288 & \multirow{2}{*}{$1: 2,3: 3,8$} \\
\hline SD & 304,2 & 55,4 & 33,4 & \\
\hline CV (\%) & 6,3 & 2,6 & 2,6 & \\
\hline
\end{tabular}

${ }^{\mathrm{d}}$ Average values obtained using an iterative process for all trees -Value not obtained.

\section{CONCLUSIONS}

The elastic behavior of Pinus radiata was studied by means of ultrasound. All elastic constants were determined for three elastic moduli, three shear moduli, and three Poisson's ratios. Mechanical compression testing was carried out to obtain the elastic moduli and Poisson's ratios and compared with those obtained by ultrasound.

The mechanical and ultrasound testing showed more similar values for the elastic moduli $\left(\mathrm{E}_{\mathrm{LL}}\right)$ along the longitudinal direction than along tangential and radial directions. For example, the elastic modulus along the radial direction presented approximately twice the values using ultrasound in comparison to the modulus calculated by the mean of mechanical testing. 
This research verified the symmetry of the shear modulus $\left(\mathrm{G}_{\mathrm{ij}}=\mathrm{G}_{\mathrm{jij}}\right)$ by means of US. This was based on the symmetry obtained for the velocities of transversal polarized waves, in agreement with the solid-state theory. Likewise, the values obtained for the shear moduli were in agreement with the literature.

In addition, the values of the Poisson's ratios obtained using ultrasound were similar to the literature for softwoods.

The ratios between velocities of longitudinal polarized waves for the three main directions of $P i$ nus radiata shown an anisotropy relationship of 1:2,3:3,8; thus fulfilling the $\mathrm{V}_{\mathrm{LL}}>\mathrm{V}_{\mathrm{RR}}>\mathrm{V}_{\mathrm{TT}}$ relationship.

\section{ACKNOWLEDGEMENTS}

This work was supported by project GI 152007/VC of Universidad del Bío-Bío and ANID PIA/Apoyo CCTE AFB170007 of Universidad de Concepción.

\section{REFERENCES}

Baradit, E.; Niemz, P. 2012. Elastic constants of some Chilean wood Species: tepa, olivillo, laurel, lenga, alerce and mañío using ultrasound techniques. Wood Research 57(3): 497-504. http://www.woodresearch.sk/ wr/201203/16.pdf

Bodig, J.; Jayne, B.A. 1993. Mechanics of wood and wood Composites. ISBN 978-0894647772. 736 p. Krieger Publishing Company: Melbourne, FL, USA.

Bucur, V. 2006. Acoustics of wood. ISBN 978-3-540-26123-0. 394 p. Springer-Verlag, Berlin Heildelberg: Germany.

Bucur, V. 1983. An ultrasonic method for measuring the elastic constants of wood increment cores bored from living trees. Ultrasonics 21(3): 116-126. https://doi.org/10.1016/0041-624X(83)90031-8

Crespo, J.; Aira J.; Vazquez, C.; Guaita, M. 2017. Comparative analysis of the elastic constants measured via conventional, ultrasound and 3-D Digital image correlation methods in Eucalyptus globulus Labill. BioResources 12(2): 3728-3743. https://bioresources.cnr.ncsu.edu/resources/comparative-analysis-of-the-elastic-constants-measured-via-conventional-ultrasound-and-3-d-digital-image-correlation-methods-in-eucalyptus-globulus/

De Borst, K.; Jenkel, C.; Montero, C.; Colmars, J.; Grill, J.; Kalisle, M.; Eberhardsteiner, J. 2013. Mechanical characterization of wood: An integrative approach ranging from nanoscale to structure. Comput Struct 127: 53-67. https://doi.org/10.1016/j.compstruc.2012.11.019

Efron, B. 1979. Bootstrap methods: another look at the Jackknife. Ann Stat 7(1): 1-26. https://www.jstor. org/stable/2958830

Efron, B.; Tibshirani, R. 1993. An introduction to the bootstrap. 452p. Chapman \& Hall/CRC: Boca Raton, FL, USA. ISBN 978-0-412-04231-7

Espinosa, L.; Brancheriau, L.; Prieto, F.; Lasaygue, P. 2018. Sensitivity of ultrasonic wave velocity estimation using the Christoffel equation for wood non-destructive characterization. BioResources 13(1):918-928.https://bioresources.cnr.ncsu.edu/resources/sensitivity-of-ultrasonic-wave-velocity-estimation-using-the-christoffel-equation-for-wood-non-destructive-characterization/

Forest Products Laboratory. 2010. Wood handbook-Wood as an engineering material. General Technical Report FPL-GTR-190. ISBN 978-1892529022. 508 p. Madison, WI: U.S. Department of Agriculture, USA. https://www.fpl.fs.fed.us/documnts/fplgtr/fpl_gtr190.pdf

Gindl, W.; Gupta, H.S.; Schöberl, T.; Lichtenegger, H.C.; Fratzl, P. 2004. Mechanical properties of spruce wood cell walls by nanoindentation. Appl Phys A-Mater 79(8): 2069-2073. https://doi.org/10.1007/ s00339-004-2864-y 
Gonçalves, R.; Trinca, A.J.; Pellegrino, D.G. 2011. Comparison of elastic constants of wood determined by ultrasonic wave propagation and static compression testing. Wood Fiber Sci 43(1): 64-75. https://wfs.swst. org/index.php/wfs/article/view/1247

Gonçalves, R.; Trinca, A.J.; Pellis, B.P. 2014. Elastic constants of wood determined by ultrasound using three geometries of specimens. Wood Sci Technol 48(2): 269-287. https://doi.org/10.1007/s00226-013-0598-8

Hernández, G.; Elgueta, P. 2020. La madera es un material de construcción sustentable. 20p. INFOR: Chile. ISBN 978-956-318-174-6

INN. 1984. Madera: parte 1: determinación de humedad. NCh176/1.Of84. Instituto nacional de normalización: Chile.

INN. 1988. Madera: parte 2: determinación de la densidad. NCh176/2:1986 Mod.1988. Instituto nacional de normalización: Chile. Instituto nacional de normalización: Chile.

INN. 1986a. Madera: determinación de las propiedades mecánicas: ensayo de compresión paralela. NCh 973/1986. Instituto nacional de normalización: Chile.

INN. 1986b. Madera: determinación de las propiedades mecánicas: ensayo de compresión perpendicular a las fibras. NCh 974/1986. Instituto nacional de normalización: Chile.

Kennedy, R.W. 1968. Wood in transverse compression: Influence of some anatomical variables and density on behavior. Forest Prod J 18: 36-40.

Keunecke, D.; Sonderegger, W.; Pereteanu, K.; Niemz, P.; Luthi, T. 2007. Determination of Young's and shear moduli of common yew and Norway spruce by means of ultrasonic waves. Wood Sci Technol 41: 309-327. https://doi.org/10.1007/s00226-006-0107-4

Konnerth, J.; Buksnowitz, C.; Gindl, W.; Hofstetter, K.; Jager, A. 2010. Full set of elastic constants of spruce wood cell walls determined by nanoindentation. In Proceedings of the International Convention of Society of Wood Science and Technology and United Nations Economic Commission for Europe - Timber Committee. October 11-14, 2010, Geneva, Switzerland. http://www.swst.org/wp/meetings/AM10/pdfs/NT-2\%20 konnerth\%20paper.pdf

Kollmann, F.; Coté, W. 1968. Principles of Wood Science and Technology. I Solid Wood. ISBN 978-3642-87930-2. 592 p. Springer-Verlag: Berlin. Germany

Kotlínová, M.; Horacek, P. 2010. Directions dynamic moduli of elasticity with transformations into anatomical. Wood Research 55(1): 11-20. http://www.woodresearch.sk/wr/201001/02.pdf

Majano-Majano, A.; Fernandez-Cabo, J.L.; Hoheisel, S.; Klein, M. 2012. A Test Method for Characterizing Clear Wood Using a Single Specimen. Exp Mech 52: 1079-1096. https://doi.org/10.1007/s11340-011$9560-6$

Niemz, P.; Aguilera, A. 1995. Untersuchungen zur Schallausbreitungsgeschwindigkeit für ausgewählte Holzarten Chiles. Holz Roh Werkst 53(3): 187-191.

Liu, J.Y.; Ross, R.J. 2005. Relationship between radial compressive modulus of elasticity and shear modulus of wood. Wood Fiber Sci 37(2): 201-206. https://www.fs.usda.gov/treesearch/pubs/20211

Perré, P.; Badel, E. 2003. Predicting of oak wood properties using X-ray inspection: representation, homogenisation and localization. Part II: Computation of macroscopic properties and microscopic stress fields. Ann Forest Sci 60(3): 247-257. https://doi.org/10.1051/forest:2003016

Royer, D.; Dieulesaint, E. 2000. Elastic Waves in Solids I. 374p. Springer-Verlag: Berlin, Germany. ISBN 978-3-540-65932-7

Sonderegger, W.; Keunecke, D.; Baradit, E.; Niemz, P. 2010. Selected physical and mechanical properties of the Chilean wood species roble, lingue, mañio and alerce. Wood Mater Sci Eng 5(1): 53-59. https://doi.org/10.1080/17480271003717279 